\title{
Literature Role in the Daily Malay Community in the Novel "Seorang Tua Di Kaki Gunung From the Perspective Theory of Pengkaedahan Melayu"
}

Nadia Ishak, Kamariah Kamarudin, Halis Azhan Mohd. Hanafiah, Haliza Abdul Rahman

To Link this Article: http://dx.doi.org/10.6007/IJARBSS/v11-i15/10631

DOI:10.6007/IJARBSS/v11-i15/10631

Received: 03 May 2021, Revised: 28 May 2021, Accepted: 25 June 2021

Published Online: 16 July 2021

In-Text Citation: (Ishak et al., 2021)

To Cite this Article: Ishak, N., Kamarudin, K., Hanafiah, H. A. M., \& Rahman, H. A. (2021). Literature Role in the Daily Malay Community in the Novel "Seorang Tua Di Kaki Gunung From the Perspective Theory of Pengkaedahan Melayu." International Journal of Academic Research in Business and Social Sciences, 11(15), 1-14.

Copyright: (C) 2021 The Author(s)

Published by Human Resource Management Academic Research Society (www.hrmars.com)

This article is published under the Creative Commons Attribution (CC BY 4.0) license. Anyone may reproduce, distribute, translate and create derivative works of this article (for both commercial and non-commercial purposes), subject to full attribution to the original publication and authors. The full terms of this license may be seen at: http://creativecommons.org/licences/by/4.0/legalcode

Special Issue: Empowering Youth and Community Wellbeing for Sustainable Development, 2021, Pg. 1 - 14 http://hrmars.com/index.php/pages/detail/IJARBSS

Full Terms \& Conditions of access and use can be found at http://hrmars.com/index.php/pages/detail/publication-ethics 


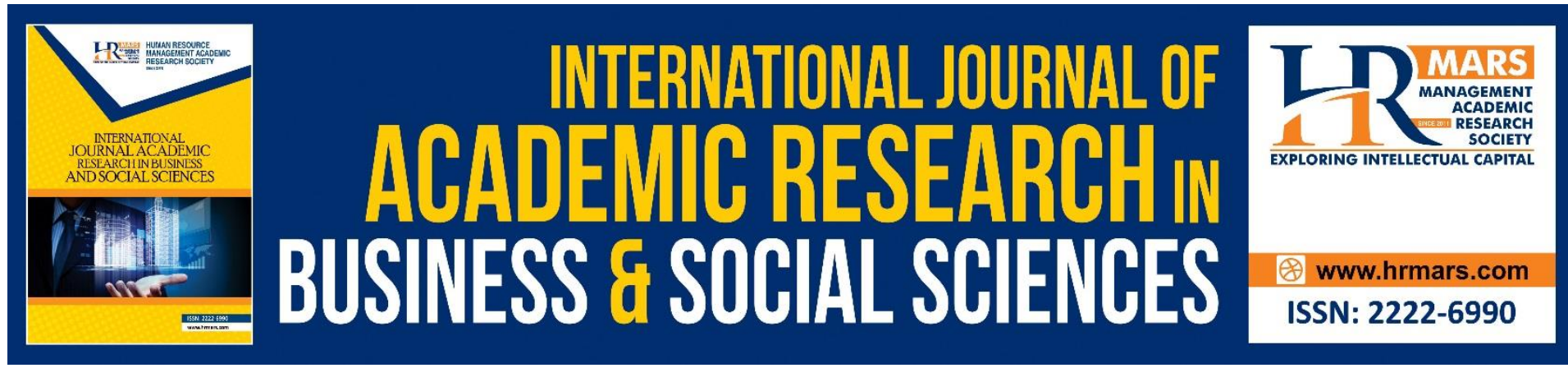

\title{
Literature Role in the Daily Malay Community in the Novel "Seorang Tua Di Kaki Gunung From the Perspective Theory of Pengkaedahan Melayu"
}

\author{
Nadia Ishak, Kamariah Kamarudin \\ Institute for Social Science Studies, Universiti Putra Malaysia, 43400 Serdang, Selangor, \\ Malaysia, Faculty of Modern Languages and Communication, Universiti Putra Malaysia, \\ Serdang, Selangor, Malaysia \\ Email:kkamaria@upm.edu.my
}

\section{Halis Azhan Mohd. Hanafiah}

Institute for Social Science Studies, Universiti Putra Malaysia, 43400 Serdang, Selangor, Malaysia, Faculty of Modern Languages and Communication, Universiti Putra Malaysia,

Serdang, Selangor, Malaysia

\section{Haliza Abdul Rahman}

Institute for Social Sciences Studies (IPSAS), Putra InfoPort, Universiti Putra Malaysia, 43400 UPM Serdang, Selangor, Malaysia, Department of Environmental and Occupational Health, Faculty of Medicine and Health Sciences, Universiti Putra Malaysia, 43400 UPM Serdang,

Selangor, Malaysia

\begin{abstract}
If enlightened the place of literature in the lives of Malay community, literature and the Malay communities are the two components that cannot be separated. Literature plays a role to upgrade the mind-set of the community in every aspect. Meanwhile, through literature communities enhance its well -being in daily life on morality towards civilization. Literature is a feeling within the soul of the author which is than translated and written out to spread on the reality happenings in human lives. Therefore, this case study is a research to literary work on how literature plays the role in the Malay community life. This research is an under lie on the novel of the Seorang Tua di Kaki Gunung (1982) authored by Azizi Haji Abdullah using the theory of Pengkaedahan Melayu as an analytical framework. This theory is by Hashim Awang, emphasizing on the ways of living, faith and the cultural of Malay Muslim community. This research data is compiled based on qualitative study and content analysis as the main instrument research. In summary, this research shows the important roles of literature in the daily Malay community life in absorbing all the principle through the theory of Pengkaedahan Melayu.
\end{abstract}

Keywords: Role, Literature, Community, Malay, Perspective, Theory, Pengkaedahan Melayu 


\section{Introduction}

The word 'literature' is a term used to describe written and spoken material. Etymologically, the word 'Literature' comes from the Sanskrit word which is castra meaning scripture. An additional of words an added at the end of a word susastera (literary art or language arts) makes a soft and harmonious meaning (Ahmad, 1994: 3). According to the Kamus Dewan Fourth Edition (2014: 1396) kesusasteraan gives a meaning of an art (written) in a form of prose or poetry which carries its own unique terms. Meanwhile, Awang (1987: 2) defines literature as an art form creation which delivers through language and is pronounce orally and in writing. Often, the meaning of literature is also known as literary work creation which is translated through writing, speaking and hearing (Piah et al, 2006: 6). Next to move on, Ashraf (1989: 36) clarifies literature as the field of art ship which covers the human life activity aspect creatively. Therefore, examining the meaning of literature which was discussed, literature broadly refers to the artwork of creativity of an author translated into widely collection of written or oral work which is used to convey a situation or a tragedy.

Apparently, literature has become non popular whereby the community has emphasis lesser due to the advancement of science and technology. However, the Malay community does not loose themselves from Malay literature. This is because the traditional Malay community is quite synonymous towards the Malay literature. For generation, the Malay literature has become a medium within its community to deliver something metaphorically and civilized. Malay literature has its implicit and explicit element, so as on this, traditional Malay communities is more comfortable to reprimand something through the art form. Malay literature (written and spoken) uses the soft and poise language of arts to deliver without offending anybody. This approach is more prudence compare to the usage of daily speaking which sometimes uses language that sound a bit harsh. This is strengthened by the Sujud et al (2008: 3) on Malay literature which is an alternative to the author on delivering dissatisfaction on the human behavioral. In this context, it is clearly shown the approach used by Malay literatures is more prudent and wiser in speaking out any warning without arising any discomfort towards local communities.

Moreover, the role of Malay literature is an element entertainment in the daily Malay tradition community which cannot be denied further. It becomes an entertainment for them after a long hectic daily working routine. In other terms, Malay literature can be used as a medium of an overall didactic guide and teaching. Advises and knowledge is spread and delivered metaphorically and implied to attract the public to adapt to its value. In short, this research will search for the role that was supported by the literary works based on theory of Pengkaedahan Melayu content of the Islam community.

This research is based on the novel of Seorang Tua di Kaki Gunung (1982) author by Azizi Haji Abdullah. The novel contents on an old mans' strong belief with his fights towards the pattern of the tradition living. It also displays the root of life in Islam community that holds strongly on their way of living, believe and tradition. The justification in choosing this novel is based on the story plot which focuses the aspect of the Islam community (believe, way of life, tradition and culture) and nature (forest, river and mountains) which is seen in this novel that has a close impact on the Malay community. Therefore, based on this element, this novel is chosen due to the alignment of content and research focus. Also, this element (living of Malay community and nature) is the main priority which is in the theory of Pengkaedahan Melayu. Thus, on this basis, it is shown that the corresponding of the novel to be the medium of research. Concisely, through this discussed context, both elements are a fundamental in the theory of Pengkaedahan Melayu will be detailed out overall to full fill the research objective 
which is to unravel the roles carried in the literary works base on the theory of Pengkaedahan Melayu.

\section{Theory and Research Methodology}

Theory of the Pengkaedahan Melayu was introduced by Awang in the year of 1989. This theory is the theory of life, believe and the culture of Malay Muslim community. Hashim Awang built this theory based on the root live and cultural of Malay community. The theory is based on the book entitled Tajul Muluk comprises vast knowledge and the guide for humans particularly in Malays. Pengkaedahan Melayu mold with the way of life and behavioral or weltanschauung, view of worldwide, natures perspective (cosmology) and Malay Muslim community which have a high and unique creations of literary work (Awang, 1999: 5-6). The theory of the Pengkaedahan Melayu divides into two elements which is the Universe Methodology and Religion Methodology. Both methods have been known entirely as an approach. The Universe Methodology is divided into three categories which are Useable Approach, Morale Approach and Prediction Approach. Meanwhile, the Religion Methodology comes with Preaching Approach, Community Approach and the Art Approach. Briefly, the theory of Pengkaedahan Melayu is seen as in Diagram 1.

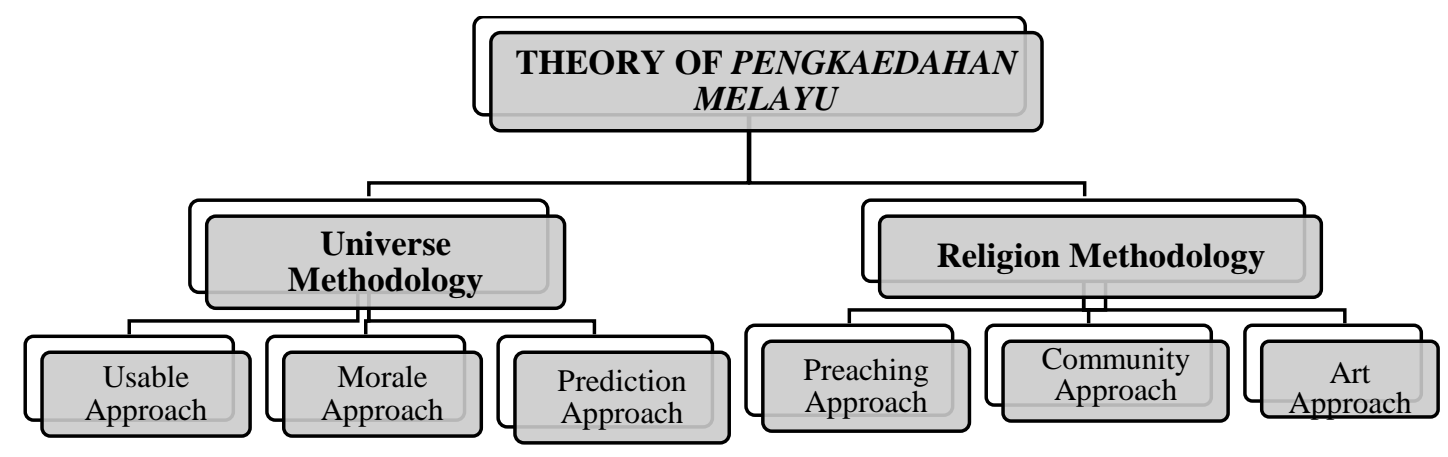

(Resources: Theory of Pengkaedahan Melayu by Hashim Awang, 2002: 12-20)

\section{Diagram 1: Theory of Pengkaedahan Melayu}

This research analysis is based on the theory of the Pengkaedahan Melayu which covers the ways of life, believes, tradition and cultural Islam Malay community. Theory of the Pengkaedahan Melayu is seen to give more roles in the literary work in the daily Malay community life looking back at its root of theory which comes from the Malay community and its surrounding. The tradition of Malay community makes their living and the surrounding as an aspiration to create a creation. Furthermore, this theory becomes a part of living and nature has its connection connected closely to humans. As known, Malay community and nature is two components which completes each other. The Malay traditional community makes the nature as a source of income, nature is seen benefiting and fulfilling this need of the Malay community in every aspect. According to Awang (1993: 53) Malay community has made nature into providing jobs, experiences, teaching and services. Parallel to this, the nature has the same connection to literary works which is created in giving benefits to mankind. Every literature created by author has the elements of education and teaching of its own for public absorption.

Hence, through this theory of Pengkaedahan Melayu, it is able to provide the roles of literary work in the Islam community lives by using all the principals which has in its theory. The theory that out louds the two main principals is the lives of the Islam community and 
nature is clearly seen in bringing out the message in welfare of Islam towards goodness. In this context, it is clearly stated that the two elements have its similarity with the theory essence of the theory of the Pengkaedahan Melayu. To that, this theory searching is related to the research focus which aims to put forward the roles which carries by literary work in Malay community life. With this the theory of the Malay methodology is seen delivering more roles of literary work in the daily lives of the community. This is due to the supply scope of Malay community life and its nature surrounding. Therefore, this theory is chosen and cannot be denied its accuracy to be embedded into this research.

\section{Analysis}

The novel of the Seorang Tua di Kaki Gunung (1982) written by Azizi Haji Abdullah is about the main character of Tukya, an old man who lives in the area of the Gunung Bongsu with his wife, Besah. They are blessed with a child named Fikri who lives in the city. Fikri has two sons. Lamin and Farid. This novel describes the contradiction of living in the village and city which caused a big gap of love between father and son. Tukya, is very comfortable living in the village compared to Farid who disapproves of traditional living which is solely in Tukya's self. The life at the Gunung Bongsu which is covered with forest and sounds of creatures has never made Tukya and his wife Besah bored. This couple lives in peace and harmonious without any lacking. The author is very fond with the love and strong family unity which will be implementing in this novel. The author also absorbed the forest and nature into the living background. Meanwhile, the aspect of living in the Malay community such as ways and behavioral of life, trust and culture is clearly seen written by the author.

Therefore, to see further on how far literature plays its role in the Malay community lives, this research will make use of all the principles in the theory of the Pengkaedahan Melayu. As stated above, this theory consists Universe Methodology (Useable Approach, Morale Approach and Prediction Approach) and Religion Methodology (Preaching Approach, Community Approach and Art Approach). All the benefits of this principle in the theory which is known and dismantles roles carried by the literary work in the daily lives of the Malay community.

\section{Literary Works Gives the Benefit and Life Experience to Mankind}

Literature is a soft medium to bring the way of thinking in the Malay community. The literature that has been produced is being able to build morality and personality. The author has to be creative in providing ideas and applying literary works with teaching and examples. In this context, literature is able to provide the benefits and living experience towards people directly and indirectly. This is proven by the touch of Hashim Awang through his Useable Approach and Moral Approach.

The Useable Approach is seen in literary works as an object or a nature's creation that brings benefits and usage towards living. Literary and nature in this context is depending on each other. The Useable Approach mentioned by Awang (1998: 9) gives pressure and focuses on the benefit of literature implied of welfare towards mankind. A good literature is shown to public and is able to be measured from the inner and outer aspects. Thus, according to Chong Ah Fok (2008: 25) the assessment figure used in literature and nature is assessed by the public's perception that assesses and interprets. This is assumed if the reader gets a pleasure through a good literature; the reader will gain benefits through reading the literature. Therefore, the creation of God such as river has thousand benefits towards mankind. Intrinsically, river is a source that provides water and food towards living creatures. 
Moreover, extrinsically, river beautifies the surrounding and nature that calms the mind and soul of a human at once is also the source of knowledge to humans and the author to create writing. This clarifies and proven that literature and nature is connected to produce quality mindset and the philosophy of the Malay community.

Meanwhile, the Moral Approach by Awang (2002: 16) is meant in the theory of the Pengkaedahan Melayu is not equal to the values known public such as manners or behavioral of good and bad or ethically. Morality herein is a meaning of recognition and teaching, the awareness of thinking and acting taking an example of teaching behind a tragedy or experience. Adding through this approach, literature is seen able to contribute towards experience and knowledge in benefiting to living creatures. Parallel to this, exposed experience in this context is about the authors experience recorded and translated in the literary works. This literary work is about the varieties of human behavioral. Therefore, the experiences will be collected to improve towards a better living.

Thus, the Moral Approach according to Awang (1999: 8) is based on the Useable Approach, which is the literary work of an event, a tragedy of a living experience. The literary work is not seen as a tool or item but as an approach that gives benefit towards personality, mysticism and human personality base on the views given. This approach is seen divided into two complete elements as experience and science. Experiences is a tragedy, or an event been through by a person in a sane way of providing a good and bad impact. Meanwhile, science is an object of information which is related to living creatures which is a meaningful information source. Literary work is seen through the Moral Approach that needs to be reviewed in a longer term. This is because, if it is explored, the process of this approach will contribute towards the indirectly benefits in mankind.

In this novel of the Seorang Tua di Kaki Gunung (1982) is a literary work giving the benefits and life experiences to mankind done by the author through the character of Fikri, the son of Tukya and Besah. The death of Tukya gives a big impact to Fikri but still he accepts the death of his father. Fikri regrets his on his behaviour, often offends his late father's feeling, Tukya. Fikri never expected that his late father will be offended with him all this time. Fikri's harsh word on his late father's house which is old and broken was taken seriously. Fikri's mother Besah is also offended with her son's words. Fikri's invitation to Besah asking her to follow him to the city is rejected because she is comfortable living in the foot of the Bongsu mountain. This will be been clearly seen in the statement below:

"Fikri is unsure if his decision to return to the city was the right decision. The decision of his mother telling him to return to the city seemed to challenge his ego as a child. How could he want to go home when at the foot of the mountain there was still a stubborn old lady."

(Abdullah, 1982: 224)

The excerpts however show Fikri regrets his doings all this while which has hurt both of his parents. Besah's decision to not following Fikri to the city after her husband's death gives as a teaching impact to Fikri for him to be more respectable towards his parents. The author utters the regrets which is deep within Fikri. In this context, Fikri is seen regretting his doings. The experience Fikri is going through gives him a teaching that he will be remembering for the rest of his life for not respecting his parents. Fikri accepts this as an experience and good teaching from this tragedy.

Meanwhile, this points that literature gives best benefits and experiences in live to mankind which is done by the author through the statement: 
"On the mattress made by pieces of cloth thick as an inch, Tukya is restless. Painlessly to the left and to the right. To sit and stand is painful. The body soar feels stiff as red as a lobster."

\section{(Abdullah, 1982: 93)}

The incident of Tukya stung by a bee at the Gunung Bongsu became the talk of the village. Tukya's stubbornness into going to the forest to find for honey has raised the anger of his son Fikri. Tukya has never thought about his age and condition when he went to Gunung Bongsu. His ego has made him do many things despite his age. His grandson Lamin too was stung by the bee in that incident. In this context, the author is seen explaining the lessons and effort from this excerpt; mankind has to accept the ability of oneself in doing something. This literary work is to give a useful experience to public. The author is seen writing on how the role of literary work gives an impact experience to mankind. However, this is aligned with the principle of Useable Approach and Moral Approach which has in the Universe Methodology through the theory of Pengkaedahan Melayu. Both this approach gives a direct experience in daily living in mankind. The author shares the information through literature using the literary works formed. People are given the ability to think for a while on an impact about an event happened. The author shares that the experiences are the bits of pieces of living compiled towards a better living for now and during death.

\section{Literature Shows the Interpretation towards a Situation or a Tragedy}

Malay community in this century often makes a situation or a tragedy happen surrounding them as an omen or a sign that something bad is going to happen. A nature phenomenon happening is something to look back in the Malay community towards natural disaster. This approach is shown by Hashim Awang through the Prediction Approach in the Universe Methodology. According to Hashim Awang, this Prediction Approach is a literary work of a tragedy or situation on nature that reveals some kind of experience which is full of mystery. In this context, the Prediction Approach is an interpretation through literature which is translated into few meanings implied. The Malay community assumes that there is a reason behind every incident that happens in their lives. Every incident happening in their lives is a sign taken as something to sit and reflect back.

Awang (2003: 18-20) characterize the Prediction Approach as below:

1. Literature is to be seen as having the inner and outer feelings directly or indirectly. This feeling is a sign in the Malay community that something bad is about to happen and is known as an omen.

2. Literature is considered as a layered discourse or metaphorical that requires interpretation work to define a meaning or content for the purpose of truth that to be delivered by the author.

3. In literature, lies the meaning of hidden content. The contents need to be analyzed and can be found through assessment of characterization.

4. Literature in this context is also shown and analyze as a formation of constitutional disclosure

This statement concludes that literature is and interpretation or an assessment with double meaning. Therefore, literature is able to unveil and give an experience of life to mankind. Moreover, something that happens naturally is able to make us to sit and think and reflect on the meaning of life of the surrounding that is happening to them. 
Through this novel of Seorang Tua di Kaki Gunung (1982), the author reveals the roles of literary work by showing on the background of the Gunung Bongsu which is full of mystery that leads to the meaning of life on humans. Gunung Bongsu is rich of nature source such as rattan, reed, honey and roots. The villagers residing at the foot of the Gunung Bongsu makes this into their daily source of income by selling it to the city communities. The author works on the character of Tukya by showing the characteristic persistence of an old man fighting for the life so that his son Fikri will never look down on him. The solidarity of Tukya and the forest has become synonym within himself. The forest is the second house for him. Tukya is more willing to sacrifice his life than to leave his life at the foot of Gunung Bongsu that is fondly attach to him. The author is seen focusing on literature which is interpreting and assessing on a tragedy. This is shown through the background of the novel which is the Gunung Bongsu. The display is seen below:

"Everything is not clear. Everything is never clear. But Tukya realized, the chengal tree outstands the other tress wanting to tell him that it is willing to wait."

(Abdullah, 1982: 68)

The above quote shows that the chengal tree that will be used to build his new house is somehow interacting with Tukya. The chengal tree is telling that it is ready to wait for Tukya to build his dream home. Tukya dont have to rush to do it. It is clearly stated that the author implies that something is being rushed into through its imaginary, Tukya communicates with the chengal tree. The finding of the chengal tree at the foot of the Gunung Bongsu enlivens Tukya's spirit to repair his old house. Tukya imagines on the sturdiness of the chengal tree which he has found. He has fixed a dream of using the chengal tree to rebuild his old broken house. Fikri's insultation on his house which is said to be old and can be broken down at any time has made his spirit even stronger to chop off the chengal tree that he has found. Tukya's fast decision to rebuild his house is actually a harsh decision. He decided to build due to the insult that his son Fikri has spoken about. Tukya has never imagined that his old age and weakness will stop him from building the new house but in fact his egoness that has accepted the challenge. In this context, the author wishes to show the message that everything needs to be done with patience. The author stress on that doing something needs to be study and cannot be taken granted. Every decision is based on mind and thoughts not by needs and feeling.

Meanwhile, the role of literature is also shown by the author through the below statement:

\begin{abstract}
"Lamin realised how much his grandfather cares for his safety as he is willing to protect him from the bees stinging. His tears roles down and before he knows few drops onto his grandfather's chest. The weird thing is that it doesn't affect Tukya."
\end{abstract}

(Abdullah, 1982: 97)

Tukya becomes weaker due to the bees stung and it really hurt Lamin as a grandchild to see the love of his grandfather has for him. Tukya feels that since he is old, and he has more immunity in himself compare to his grandchild who is still small and young. Moreover, this is clearly to be seen with the writing of Azizi Haji Abdullah is proven that the roles of literature as a function of interpretation on a situation or tragedy. This tragedy is seen how the love 
bond is between a grandfather and a grandchild. The blood ties between them are an example to the public to learn to appreciate elderly. In this context, the author provides an interpretation beyond the happening as something meaningful in their lives. This is to be judged and reflect as an eye opener of the meaning behind it. Therefore, this is aligned with the theory of the Pengkaedahan Melayu through the principle which is from the Prediction Approach in the Universe Methodology.

\title{
Literature as a Preaching Medium
}

As stated before, the theory of Pengkaedahan Melayu includes two methodologies which is the Universe Methodology and the Religion Methodology. As for the Religion Methodology, it is parted into three approaches which is the Preaching Approach, Community and Art. Basically, these three approaches are connected with each other. The Religion Methodology leads to the approach of the importance in Islam religion. As known widely, the religion that is by Malay community is Islam. Islam is the religion by the Almighty through Prophet Muhammad SAW.

Through the Preaching Methodology which has in the Religion Methodology, this approach shows literature as a medium to improve the values of piety and faith of mankind towards their Creator. According to Awang (1994: 15) the Preaching Approach sees literature as a tool to spread Islam in the context of appreciation and excellence of God. Moreover, through this approach, literature is also seen mentioning about the additional of Islam religion which will create an attraction towards the Islam and non-Muslim. Literature becomes a reference place to get to know more on the purity of Islam teachings and increases the bond and feeling of love towards the Almighty.

The novel of the Gunung (1982) has shown carrying many questions of beauty and excellence of the Islam religion. The literary work generated by the author displays preaching's doing directly and indirectly. This shown through the main character of the novel which is Tukya that is portrayed by the author as a man who believes in Islam teaching. The praises by Tukya towards the Almighty indirectly becomes the medium preaching to public to learn more deeply and purity of Islam. This can be seen by the below text:

\begin{abstract}
"Tukya looks back at the past. Not sure why he ends up at the foot of the mountain... The power of the Almighty he learnt twenty years back during his teenage time is based on argument that the land he steps on is the power of the Almighty."
\end{abstract}

$$
\text { (Abdullah, 1982: 19) }
$$

Through this context, the author talks on Tukya that is staring to his future of life on the foot of the mountain. Tukya states his trust is to the Almighty that is the creator of the universe. Therefore, Islam encourages to always remember of His greatness and oneness of the Almighty. It is concluded that mankind always reflects back and think of the completion of nature which adds their faith towards God. Tukya is the main character of the novel Seorang Tua di Kaki Gunung (1982) which has high values of morality and faith in God. The author focuses on the statement that is seen how literary works delivers as a medium preaching to Islam religion on the greatness of the Almighty. 
Other than that, the roles of the literature points as a medium preaching are also shown by the author as below:

"After prayers, Tukya prays for very long. Besah is also praying together. And that is what actually Tukya is often doing, praying. All this praying is to ask God to make sure everything goes on well."

(Abdullah, 1982: 68)

Tukya praying is his daily routine. The author implies Tukya's overall prayers are not only for his well-being but also for the good of forest and mankind. In this context, the author shows that Tukya makes it a habit to pray and is the teaching of Islam. In this seen character, the author carries the importance of love between Islam religion and well-being. It is also clearly explaining that in Islam, praying for oneself is not the only thing, but also praying for the overall of nature and for the mankind as well.

Therefore, it is shown that the author manages to show from both statements that praises, and the greatness of the Almighty is one of the roles carried by literary work as a medium preaching to community. Also, the authors approach is to focus on the greatness of the creator and to make people believe how powerful and one has to bow to the Almighty. Basically, Tukyas' character is about having faith being a Muslim. This can be read in the writing by Azizi Haji Abdullah as preaching is an element to Islam. So, the perfectness of this research, the role of literary work is clearly shown as a role in preaching. Therefore, this is aligning with the principle of the religion methodology through the theory of the Pengkaedahan Melayu by the aspect of literary work as community being the preaching medium.

\section{Literature Role in Finding the Good and Lawful in Community}

Community Approach is one of the elements in the Religion Methodology. This approach is used to find fairness and good in community which aligns with the teaching of Islam. It is also an approach to find peace and harmony living in the Islam community base on faith and believe. This is firmly stated by Hashim Awang using the below statement:

"As an art with the priorities of intellectual and magnificence, literary work in this context is according to reveal with bravery, clearly and truthfully the problems arising from default, dishonesty, wickedness and oppression. All this causes is being one of the flaws in the community and is the breakup in Islam community."

The approach makes literature as a tool that uses to voice out all questions relating to community in finding the truth and justice to the road of the Almighty. Community Approach is seen motive of well- being in the community and it is believed that it can strengthen the believes on Islam religion. Therefore, this approach is adapted as a special mission giving wellbeing towards Islam community.

Meanwhile, through the novel of Seorang Tua di Kaki Gunung (1982) the author mixes the character of Tukya and is shown to people that literary work manages to teach and guide the people of Islam. Author is also seen assessing and analyzing based on the teaching of Islam publicly through the good and lawful morality. This is seen by below: 
"Since the age of twenty-one, this is the first night Tukya did not pray. His pain has made him failed in his faith towards prayers. As long as God forgives him, and he shall continue praying when he gets better again. Tukya knows, it is not possible to stand and pray but it must also be performed even in a state of sleep. But Tukya could not do that. May God forgive my sins, he thought."

(Abdullah, 1982: 92)

The above quotes show the health condition of Tukya being sick due to the bee stinging. Tukya is stung by the bees during his finding for honey at the peak of Gunung Bongsu. Tukya wants to do his prayers but he is very sick and that has made him very weak to pray due to his age. The author reveals Tukya personality by showing the main role is not forgetting God even though he is in problems. Tukya feels bad that he is not praying he knows that no matter what situation prayers is a must. Tukya promises to pray and repent all the prayers he missed after he gets well. Prayers must be carried on even during, war, sick, poor or in emergency.

Author shows the role of literary work as a preaching medium through the below excerpts:

"What benefits Lamin from this forest." Fatimah is seen forgetting to respect Tukya as her father in law. Tukya was shocked and looked at Fatimah arising a question deeply within him, as is Fatimah his daughter in law. "What is the benefit to Lamin, questioned Fatimah forgetting her respect."

(Abdullah, 1982: 125)

Fatimah's rudeness is seen when she indirectly clinging Tukya on his stubbornness in going to the Bongsu mountain to find honey. Fatimah is more angry because Lamin her son followed Tukya when the bee stung him. Tukya is being blamed on his selfishness and clumsiness for not thinking of their safety. In the anger of Fatimah, she spoke harsh words that were not supposed to be heard of. The author composes of the character of a daughter in law as not respecting the elderly so that the audience will take note as a teaching from this novel. Accordingly, through this both phrases it is clearly seen how the author through his literary works teaches and gives an example and guide to community to be better in life. According to $\mathrm{Hj}$. Selamat and Che Ya (2010: 23) the literature plays a role in delivering a message to people. This message is on the fight and lifestyle of surrounding community. Based on the research done, the role of literature is seen as a finding for good and justice in community. Literary work can be said to be a mode or a tool towards education that gives teaching, message or guidance to community to get a better life. In this context, Community Approach focuses on the element of doing good and well-being. This is exactly with the function of Islam literary which is self- inspired and translated by the author to perfectly fit in the mankind lives. This is aligned with the theory of Pengkaedahan Melayu through the principle in the Community Approach in Religion Approach from the aspect seen in literature in finding the good and rightfulness in community. 


\section{Literature Delivers Information Figurative and Implicit}

Generally known Malay community makes literary work as a tool of entertainment. Malay community at one point of time makes literary work of writing or verbally as an art to bring the happiness in a situation after their daily routine. In another words, it is seen as an entertainment. Literature is a didactics medium between the Malay community and seen showing guidance towards people to absorb moral values in it. This is delivered by the author directly and indirectly. To deliver something implicit, people will be able to assess and use it easily meanwhile to deliver something explicit, it requires a study specifically to assess the meaning. Therefore, this discussion is indirectly playing the role of literary work in delivering a meaning veiled and implicit.

Hashim Awang through the Art Approach in the theory of the Pengkaedahan Melayu is seen pointing that the aspect of aesthetics or beauty is seen the function to deliver something figuratively and implicitly. The beauty aspect is seen in words, proverbs and speech. Malay community makes literature as a medium to provide something prudent and softer. This is because the language used is softer and doesn't hurt anybody. It is also more respectable compare to the daily usage which is quite rude. The Art Approach is an approach which is more on the Islam aesthetics in literature. This aspect of usage is seen in physically and spiritually. The physically beauty is visually in the usage of language while the beauty of spiritually is in the mind and speech brought in literary work. Though this is based on the Islam. According to Lubis (1994: 6) the beauty of completing and uttering is towards the Almighty. The claims of the beauty aspect are controled by faith and Islam teaching is to safe guard the perfections in literary work.

The novel of Seorang Tua di Kaki Gunung (1982) seen showing an aspect stated in the novel by the author on moral values and is an example to people. This is delivered implicitly to people through the message in it. The author reveals this through the character of Besah the wife of Tukya. Besah is shown as a loving and dedicated wife towards her husband Tukya. Tukyas' death gives a big impact, but she accepts her faith. Besah continues to settle her life at the foot of the mountain surrounded by the forest and night creatures. Fikri's invitation to stay in the city is rejected humbly. She is seen distracted by the invitation because her memories with late Tukya are at foot of the mountain which cannot be forgotten. This can be seen in the below quote:

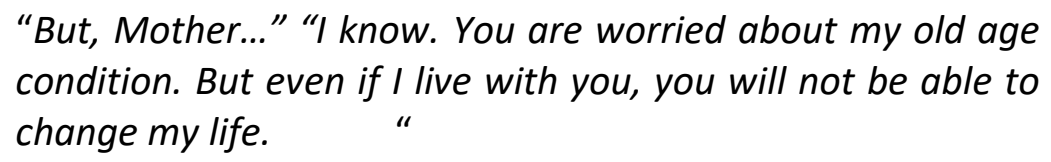

(Abdullah, 982: 222)

Clearly stated in the character role Besah is seen by the author that doesn't want to hurt her sons feeling. Fikri's invitation to stay with him in the city is rejected softly without trying to hurt his feeling and she prefers to stay in the village. She explains secondly that she knows how to take care of herself as good as how her late husband took care of her. Besah strictly explains to Fikri that she is old and the fact that he cannot change it. Living in city won't be able to change her and she is comfortable and used to living in the village. The other reason Besah is refusing because of Fikris arrogant way of hinting living in the village. Through this finding, clearly noted that the author stresses that literary work is seen delivering something figuratively and implicitly. The dialogue thrown by Besah to her son shows how soft the usage of language used for the purpose of not hurting anyone hearing. 
Meanwhile, in another context, the author seen on the literary work in delivering the meaning directly and indirectly through the quotation:

"If this old house is the reason for your kids to make fun than

it is ok if even if you don't return to visit". Tukyas' words softly

saying in the dark.

(Abdullah, 2982: 127)

Tukya is very sad with the character of Fikri as how he forgot the root of his life. Fikri was born and raised in the Forest of Bongsu Mountain until he successfully finished his studies and manage to get a good job in the city. His success has made him an arrogant person. The quote clearly reads how Tukya indirectly says that he regrets on Fikris' behavior. Tukya prefers Fikri not to return to the village than keep hurting his old heart feelings. Every word thrown by Tukya has double meaning on his regret from a father to a son. Again, the author is trying to deliver that the language used, and its meaning has its implicit and explicit. Therefore, through this research done, the role of literary work is seen clearly as delivering directly and indirectly. The message by Azizi Haji Abdullah is delivered with a phrase symbolic to translating the double meaning. The aspects of beauty are a very important element in a literature. It increases the interest of people to deepen into the literature. It also makes a human to be more humane. Therefore, this is aligned with the Art Approach which is in the Religion Methodology through the theory of Pengkaedahan Melayu.

\section{Conclusion}

Based on the research done, it is clearly shown that both main elements which is the Islam community living and nature is able to unravel and forward the roles carried out in literary works base on the theory of Pengkaedahan Melayu. Moreover, the content of novel that is used in this research is seen aligning with the main objective and research. Besides, based on the research done, also seen that the principals in the theory of Pengkaedahan Melayu (Universe Methodology and Religion Methodology) is seen that in each and every of it is able to be sure on the roles of the literary works in the lives of the Malay community done in this research. In this context, the theory of Pengkaedahan Melayu is fair to use as the main reference for research literatures in searching through the importance of literary works in lives especially in the Islam community. In other words, this scenario is seen in the novel Seorang Tua di Kaki Gunung (1982) is able to be a tool in education towards the perfect way for Islam community. Hence, this element has been worked on by the author to guide towards the goodness of wellbeing in Islam community. The theory that has been absorbed through this novel has given a good impact towards the lives of Islam community especially because the question and problems arise to manifest the piety of Islam towards Allah SWT. Other than that, the choosing the theory of Pengkaedahan Melayu is enough to signify in this research. This is because; this research provides enough scope in the literature roles that influences the research analyses. As conclusion, the choosing of theory is to propose the roles of literary work in daily community lives. All the theories fully beneficially use in providing the roles of literary work. The theory is developed based on the views of values of Islam seen in the roles of literature. Meanwhile, the theory of Pengkaedahan Melayu reveals the culture, faith and believes of the Malay Muslim community. Also, through the theory of Pengkaedahan Melayu, almost every living of physically and spiritually of Malay race is being explored and has made as an essence in this theory. Therefore, this theory is proven to critic, analyzes and values the outcomes of the Malay literature. 


\section{References}

Ahmad, A. (1994). Pengantar Pengajian Kesusasteraan. Kuala Lumpur: Dewan Bahasa dan Pustaka.

Ashraf, S. A. (1989). Horison Baru Pendidikan Islam. Jakarta: Pustaka Firdaus.

Awang, H. (1987). Glosari Mini Kesusasteraan. Petaling Jaya: Penerbit Fajar Bakti Sdn. Bhd.

Awang, H. (1993). Teori Pengkaedahan Melayu dalam Kajian dan Kritikan Kesusasteraan Tanah Air. Dewan Sastera. Kuala Lumpur: Dewan Bahasa dan Pustaka, 52-57.

Awang, H. (1998). Teori dan kritikan kesusasteraan Melayu di Malaysia. Pangsura, Bil. 6 Jil. 4. Bandar Seri Begawan: Dewan Bahasa dan Pustaka.

Awang, H. (1999). Teori Sastera Sendiri: Pengkaedahan Melayu. Kolokium Membina Teori Sastera Sendiri. Kuala Lumpur: Dewan Bahasa dan Pustaka.

Awang, H. (2002). Teori Pengkaedahan Melayu dan Prinsip Penerapannya. BengkelTeori Sastera, anjuran Dewan Bahasa dan Pustaka, Kuala Lumpur di Riviera Bay Resort, Melaka.

Awang, H. (2003). Sejarah Kesusasteraan Melayu Moden: Esei Kritikan. Kuala Lumpur: Dewan Bahasa dan Pustaka.

Chong, A. F. (2008). Kajian Terpilih Brunei Darussalam Dari Perspektif Pengkaedahan Melayu. Bandar Sri Begawan: Dewan Bahasa dan Pustaka Brunei.

Kamus Dewan Edisi Keempat. (2014). Kuala Lumpur: Dewan Bahasa dan Pustaka.

Selamat, J. H., \& Ya, C. A. A. (2010). Analisis Teks Cucu Tuk Wali Menggunakan Pendekatan Kemasyarakatan. Jurnal Personalia Pelajar, Bil: 19-36.

Lubis, M. B. (1994). Estetika dalam Kesusasteraan Islam: Beberapa Pengamatan. Dewan Sastera, 6-9.

Piah, H. M., Hamid, I., Salleh, S. H., Sham, A. H., Kaeh, A. R., \& Ahmad, J. H. (2006). Kesusasteraan Melayu Tradisional (Edisi Ketiga). Kuala Lumpur: Dewan Bahasa dan Pustaka.

Sujud, A., Affendi, N. R. N. M., \& Rahman, A. A. (2008). Sastera Melayu: Suatu Pengantar. Kuala Lumpur: Tinta Pres. 